\title{
Die Wese van die Geloof.
}

Waar ons op 31 Oktober weer dink aan die werk van die Hervorming, daar is dit nodig dat ons weer die aandag vestig op die geloofsworsteling van die manne van die Hervorming. Om daardie geloofsworsteling te verstaan is dit nodig om te let op die wese van die geloof. En om die wese van die geloof te verstaan is dit nodig om eers te let op die geloofsopvatting van Rome. Ons moet eers daarop let hoe Rome die verband tussen geloof en Skrif soek. Rome het hierdie verband verduister deur die geloof te bind aan die kerk, wat egter self die Woord nodig het om te bestaan. Die geloof is ' $n$ loutere toestemming van wat die kerk leer, 'n simplex assensus. Dit is onvoldoende tot regverdiging. Dit is een van die sewe preparasies, maar in sigself is dit informis. Die liefde moet daarby kom. Deur die liefde word die fides informis verander in 'n fides formata. Die gelowiges moet alleen glo wat die kerk glo, ook al verstaan hulle dit nie. So het die mensonterende leer van die fides implicita ontstaan, ' $n$ ingewikkelde geloof.

Rome spreek dan ook byna altyd net van die fides quae creditur wat die leer behels. Die fides qua creditur, die geloof as vermoë, ken Rome nie. Daarom is by Rome die geloof geen fiducia op Gods barmhartigheid in Christus soos Luther leer nie, ook nie 'n cognitio in die sin 
wat Calvyn dit opvat nie, maar 'n simplex assensus. Dit is 'n assensus intellectualis. Omdat die geloof 'n loutere toestemming is van die waarhede wat deur God geopenbraar is en deur die kerk bewaar word, kan dit ons nie waarlik met Christus verenig nie tensy die hoop en die liefde daarby kom, "sine spe et caritate praestare fides non potest" (Trid., sessio VI, C. 7).

In die geloof kan selfs die notitia gemis word as die wil maar daar is om te glo wat die kerk glo (Cat. Rom. I, 2, 3). Dit is selfs gevaarlik om te diep in die inhoud deur te dring. Die werking van die geloof kan dus nie bestaan in ' $n$ vereniging met Christus nie, maar dit moet bestaan daarin dat elkeen hom aan die kerk beskikbaar moet stel sodat die kerk sy werk aan die gelowige kan doen. Daarmee stel Rome die saligmakende geloof op een lyn met die historiese geloof en misken dit die religieuse natuur daarvan. Die geloof word immers voorgeskrewe deur die menslike rede. Daarom het die Vat. Kons. sy vloek uitgespreek oor hulle wat dit ontken. Volgens Rome is vertroue nie die geloof self nie, maar 'n gevolg en vrug van die galoof. Hierdie vertroue kan nooit absolute sekerheid gee nie. Waar Rome also die band van die geloof na die kerk verlê het, daar het dit die Christendom tot sterwens toe verswak en het dit 'n nuwe reformasie nie alleen na die inhoud nie maar ook in die vorm van die geloofslewe noodsaaklik gemaak.

Die geloof is vir ons ' $n$ instrument wat ons met Christus in die gemeenskap met al sy goedere hou. Rome egter beskou die geloof as 'n goeie werk van die mens. Die $H$. Skrif leer ons dat die regverdige uit die geloof lewe. Dit is geen wonder dat die reaksie van die Hervormers teen hierdie verwronge opvatting van die geloof deur Rome so kragtig was nie. Die geloof tog moet veranker wees in die Skrif en nie in die kerk nie. Die geloof was vir die Hervormers 'n hooftema van die stryd. Geloof was vir hulle gelykluidend met Christus. Hulle sien dit nie in die eerste plek as band aan die kerk of Bybel nie, maar as gemeen. skap met Christus self. Die geloof bind ons wel aan die Skrif, maar nie meganies enkel as boek van waarheid nie, maar persoonlik aan die beloftes van God wat daarin vervat is, dus aan die lewende God self wat Hom daarin uitspreek. Die geloof is dus 'n persoonlike verhouding tot, ' $n$ band van die siel aan Christus. Die geloof het dan ook ' $n$ spesiale objek, en hierdie objek is nie die geopenbaarde waarhede nie, soos Rome leer, maar bepaaldelik die divina benevolentia in Christus en nog meer bepaald die vergewing van sondes. Hierdie vergewing kom nie deur die geloof tot stand nie maar gaan aan die geloof vooraf en word 
deur die geloof alleen aangeneem. Hier word die geloof nog as 'n eenheid opgevat. Die Hervormers het nog gelewe, uit die geloof en het hulleself nog nie logies rekenskap van die geloof gegee nie.

Maar die omstandigluede het hulle daartoe gedwing om ondersoek in te stel na die acird en samestelling van die geloof. Dit kan gesien word as bewys van verswakking van die kerk. Rome was op sterwe na dood. Maar die Hervorming was dan ook 'n teken van herlewing, 'n reaksie teen die dood. Die ontleding van die geloof dra dan ook 'n mediese karakter. Dr. Wielenga sê: „Hier wordt de waarheid ontleed (in Kat Sondag 7), beschreven, als medicijn toegediend, om te genezen, de spankracht en levensvreugd te verhoogen. Het geloof moet weer zijn hei normaal beschikken over de schatten van Christus, het leven uit die Heer van alle schatten. Gelukkige kerk der Hervorming"!

Ons dank die Here dat dit deur sy genade tot 'n deurbraak in die wese van die geloof gekom het. Die reformatoriese geloofsbegrip is vercusend moeilik om psigologies en teologies te begryp. Ons het hier geen ruimte om die geloof by verskillende Reformatore na te gaan nie. Ons wil die aandag hier slegs vestig op die opvattings van Calvyn en die Heidelbergse Kategismus.

Vir Calvyn is geloof kennis, cognitio, in teenstelling met die Roomse fides implicita. Die geloof is 'n gewisse kennis van Gods welwillendheid teenoor ons. Hy omskryf die geloof deur cognitio en nie deur fiducia nie. Die fiducia lei hy af uit die geloof. Die geloof staan van nature teenoor alle twyfel en sluit die gewishiid van die persoonlike saligheid in. Calvyn sien in die geloof 'n onwrikbare vaste oortuiging wat op die objektiewe waarheid rus. Dit is die persuasionis certitudo. Die geloof steun voorwerplik op Gods Woord maar word onderwerplik in ons gewerk deur die Heilige Gees. Gods Gees beseël die waarheid deur die geloof in ons hart. Die geloof is eintlik meer 'n saak van ons hart as van ons verstand: cordis magis quam cerebri. Dit wys daarop dat Calvyn by die cognitio wat hy aan die geloof toeskrywe, nie aan 'n verstandelike kennis dink nie maar aan 'n oortuiging wat setel in die verstand marar tog wortel in die hart. Dit is nodig om hierop te let, want die kennis van God is by Calvyn altyd teologies, nie van God in abstracto nie maar in Christus en in die Heilige Skrif geopenbaar in die beloftes.

Sommige het Calvyn beskuldig dat hy te weinig ' $n$ hart gehad het en dat hy te logies was. Dit is nie waar nie. Calvyn het nie 'n ver- 
standelike kennis van die waarheid gehad nie, maar 'n persoonlike toestemming van die waarheid, en dit is geen intellektualisme nie (Jer. 53: 11; Joh. 17: 3). Calvyn het kennis opgevat as 'n eienaardige bepaling ten opsigte van sy kwaliteit en hy het dit gehandhaaf as religieuse kennis. Die saligmakende geloof as cognitio aanvaar as met een akte Christus as Saligmaker $\in n$ die Skrif as Gods Woord. Dit ken en neem Christus aan in die gewaad van die Heilige Skrif en vermy dus sowel die dorre rasionalisme as die valse mistisisme. Dr. Bavinck beweer dan ook tereg: „Er is eigenlijk al geen schooner definitie denkbaar dan deze, dat het geloof een vaste en zekere kennis is van de barmhartigheid, welke God in Christus ons heeft betoond" (Geref. Dogm., 3de druk, IV, p. 121). Dr. S. P. Dee beweer dan ook: „Calvijn wil zijn lezers doen voelen dat het geloof niet maar een verstandelijk voor waar houden is, maar een stellige, cntwijfelbare, affectieve zekerheid, dat ik persoonlijk God tot mijn God en Christus tot mijn Zaligmaker heb" (Het Geloofsbegrip van Calvijn, bl. 9).

Die vraag is waarom Calvyn die kennis in die wesensdefinisie van die geloof so sentraal maak dat die vertroue 'n deel van die kennis genoem word. Die rede daarvan moet ons allereers hierin soek dat die geloof vir hom sekerheid, onwrikbare, gewisse oortuiging is. Dit is formeel nie aan die wil nie, maar aan die verstand toe te ken. Dan kom daar in dis tweede plek by dat die vertrouenselement wel in die term cognitio tot uitdrukking kom, maar onigekeerd kom die kenniselement nie tot uitdrukking in die term fiducia nie. Vertroue is 'n akte alleen van die wil. Die kennis mag daar as praerequisitum noodsaraklik aan voorafgaan, maar dit lê nie in die begrip fiducia opgesluit nie.

Die geloxfsbegrip van Calvyn stann dus diametraal teenoor dié van Rome. Die opvatting dat die geloof by die Gereformeerdes 'n blote verstandelike toestemming is van die leerstukke wat in die belydenis vervat is, word hier by die wortel afgesny. By Calvyn blyk dit so duidelik dat die eienaardige van die Reformasie dit was dat dit die geloof van die verstandelike na die religieuse terrein oorgebring het. Die egte saligmakende geloof was van huis uit van alle ander geloof onderskeie. Dit sluit die pius affectus in. Dit het also prinsipieel teenoor Rome gestaan. Dit konklusie waartoe dr. Dee kom, is : „zoo blijft dan aan Calvijn de eer de natuur van het geloof het best begrepen en het zuiverst geformuleerd te hebben. Hij betoont zich hierin theoloog der Reformatie bij uitnemendheid"' (a.w. 212). 
Ons Heidelhergse Kategismus definieer die geloof as: „nie alleen 'n gewisse kennis waardeur ek alles vir waaragtig hou wat God aan ons in sy Woord geopenbaar het nie, maar ook 'n vaste vertroue wat die Heilige Gees deur die Evangelie in my hart werk dat nie alleen aan ander nie, maar ook aan my vergewing van sondes, ewige geregtigheid en saligheid deur God geskenk is uit loutere genade alleen terwille van die verdienste van Christus" (Vr. 21). Hierdie definisie is ontleen aan Melanchton se Examen Ordinandorum. Hier word kennis en vertroue in 'n juxtaposisie gestel: „nie alleen maar ook”. Bavinck beweer: „De fiducia drong de cognitio als van minder waardij op den agtergrond" (IV, p. 122). Die indruk wat ons hier kry is dat die geloof bestaan in 'n blote verstandelike aanvaarding van die Skrif as Gods Woord en in die vertroue op Gods vergewende genade in Christus. Ursinus beweer dan ook self ,dat het rechtveerdighmakende geloof altijd het historische mede in sich begrijpt" (Schatboek, 1657, p. 72). Sommige beweer dat die verstandelike toestemming van Gods Woord hier 'n affektiewe karakter dra. Die definisie van die Heidelbergse Kategismus bevat 'n sekere dualisme. Dit definieer die geloof as nie alleen 'n gewisse kennis nie maar ook 'n hartlike vertroue. Hierdie dualisme het spoedig daartoe gelei om die kennis in die saligmakende geloof nog wel vas te hou maar die swaartepunt tog in die vertroue te lê. By Calvyn het kennis en vertroue in organiese verband gestaan. In die eerste tyd het hierdie juxtaposisie van kennis en vertroue nog nie veel kwaad veroorsaak nie. Maar namate die religieuse lewe agteruitgegaan het en die dooie ortodoksie gaan heers het, moes daar wel reaksie kom. Die kennis is steeds meer gedegradeer. Daar is nog wel toegegee dat kennis 'n praerequisitum van die geloof is, maar die wese is gestel in die vertroue van die hart. Die geloof as fiducia is langsamerhand losgemaak van die cognitio van die openbaring. Die gevaar van mistisisme het gaan dreig.

Hierdie tweërlei rigting vind ons by Comrie en á Brakel.

P. J. S. DE KLERK. 